\title{
Multi-Temporal Analysis of Land Subsidence in Toluca Valley (Mexico) through a Combination of Persistent Scatterer Interferometry (PSI) and Historical Piezometric Data
}

\author{
Norma Davila-Hernandez ${ }^{1}$, Delfino Madrigal ${ }^{1}$, Jose Luis Exposito², Xanat Antonio1 \\ ${ }^{1}$ Laboratory of Remote Sensing and Geographic Information Systems, Faculty of Geography, Autonomous \\ University of Mexico State, Toluca, Mexico \\ ${ }^{2}$ Department of Hydrology, American Center of Water Resources, Atlacomulco, Mexico \\ Email: ${ }^{*}$ nadavilah@uaemex.mx
}

Received 25 February 2014; revised 25 March 2014; accepted 10 April 2014

Copyright (C) 2014 by authors and Scientific Research Publishing Inc.

This work is licensed under the Creative Commons Attribution International License (CC BY).

http://creativecommons.org/licenses/by/4.0/

(c) $\underset{\mathrm{EY}}{\mathrm{B}}$ Open Access

\begin{abstract}
The Toluca Valley Aquifer (TVA) is considered one of the most overexploited aquifers in Mexico because of the high rate of groundwater extraction for supplying urban and industrial water to Mexico City and Toluca City, which causes land subsidence in urban and suburban areas. In this paper, we propose a multi-temporal analysis that uses persistent scatterer interferometry (PSI) method to evaluate the subsidence processes in Toluca Valley. The PSI results revealed differential movements of the ground of as much as $83 \mathrm{~mm} /$ year. A spatial variation of PSI results was identified with respect to previous studies using the conventional Din SAR methodology. The spatial distribution and density suggested the possibility of an expanding trend of subsidence process at north, northeast and east of the TVA, which corresponds to the region with the highest density of pumping wells for industrial and agricultural use.
\end{abstract}

\section{Keywords}

Subsidence of Lands, Toluca Valley Aquifer, Persistent Scatterer Interferometry

\footnotetext{
${ }^{*}$ Corresponding author.
} 


\section{Introduction}

Differential movement of ground is caused by geological instabilities at different scales and depths. Specifically, most subsidence in urban areas results from anthropogenic causes: gradual settlement of soil results from groundwater overexploitation, which is principally associated with irrational use of pumping wells. The steady decline of groundwater levels leads to soil compaction, particularly on porous granular material, which causes soil faults, fissures, or vertical movements. Although land subsidence occurs on the scale of millimeters, with time, it causes the significant damage to urban and rural infrastructure.

Radar data have been demonstrated to be effective for multi-temporal monitoring of land subsidence in densely urbanized environments [1]-[11]. In the last ten years, differential synthetic aperture radar interferometry (DInSAR) has been the most conventional technique for evaluating any type of vertical ground movement, such as volcanic activity [12]-[14], glacial retreat [15] [16], slope mass movements [17] [18], coal mining [2] [19], and tectonic process [20]-[22]. However, the most significant limitation of using DInSAR observations taken in multiple passes is the decorrelation of radar information. This decorrelation is caused by several error sources, including temporal decorrelation due to physical terrain changes, low coherence due to changes in the backscattering mechanisms of the signal, and principally, delay in phase propagation as a result of the signal's interaction with atmospheric conditions [23]-[25]. Persistent scatterer interferometry (PSI) is a method developed by Ferreti et al. [1] [26] [27], in which the land deformation may be detected at the scale of millimeters. Unlike traditional DInSAR, PSI permits reducing the atmospheric phase contribution considerably by selecting backscatter points or "persistent scatterers" (PSs), which serve as "coherence pixels" because the magnitude of the radar signal at these points should remain constant throughout the synthetic aperture radar (SAR) time series. These PSs enable one to filter out the phase linked to atmospheric effects from the SAR time series data. The selected stable reflector PSs usually correspond to urban areas, which host manmade structures that are not affected by residual noise or temporal decorrelation. In Mexico, several studies have used DInSAR and PS techniques to assess subsidence processes within principally urban zones in the center of the country that are principally affected by groundwater overexploitation [4] [8] [11] [28]-[30]. In this paper, we studied the subsidence processes in the Toluca Valley Aquifer (TVA) and its surroundings during the period 2003-2010 based on multitemporal Envisat-ASAR images and historic piezometric data. In contrast with previous work [28] [29], we used PSI because it has been demonstrated to be the most accurate method for collecting data regarding vertical ground deformation in urban environments.

\section{Characterization of Study Area}

Toluca City (TC) is located $70 \mathrm{~km}$ west of Mexico City (MC), is part of the TVA, and belongs to the upstream basin of the Lerma River in Central Mexico. The study area extends in latitude from $19^{\circ} 9^{\prime} 30^{\prime \prime}$ to $19^{\circ} 24^{\prime} 18^{\prime \prime}$ and longitude from $99^{\circ} 28^{\prime} 36.10^{\prime \prime}$ to $99^{\circ} 47^{\prime} 27^{\prime \prime}$ and covers an area of $900 \mathrm{~km}^{2}$. Nearly 1.8 million people live in TC. However, the population is increasing in the western, northern, and northeastern areas of the city. Land use within TC and the surrounding areas is characterized by habitation, seasonal agriculture, and industrial corridors along the eastern valley (Figure 1). Because of poor land-use planning within TC, new residential and industrial development has occurred in the aquifer recharge zone north and east of the hydrological basin. This spatial disorder has negatively impacted the environment by decreasing the TVA groundwater level. In turn, groundwater withdrawal has caused clay-soil compaction and land subsidence.

\section{The TVA and Geology}

The proximity of the TVA to Mexico Valley is another negative factor for the TVA. MC is located in the Mexico Valley, $70 \mathrm{~km}$ from the TVA. Nearly 20 million people live within the MC metropolitan area, and it is ranked among the top-10 most populated in the world. Since 1952, approximately 256 pumping wells were built throughout the TVA to supply drinking water to MC. To date, more than 500 pumping wells have been distributed within the TVA and represent $30 \%$ of MC's water supply. The increased drilling of pumping wells around urban and industrial areas has also caused the gradual extinction of springs, wetlands, and groundwater recharge areas [31]. The TVA has become the second-most overexploited aquifer in Mexico [32].

The TVA is a volcanic aquifer with high permeability due to its fractured basaltic bedrock. It is bordered on the east by the Sierra Chichinautzin mountain system and on the west by the Nevado de Toluca volcanic system. 


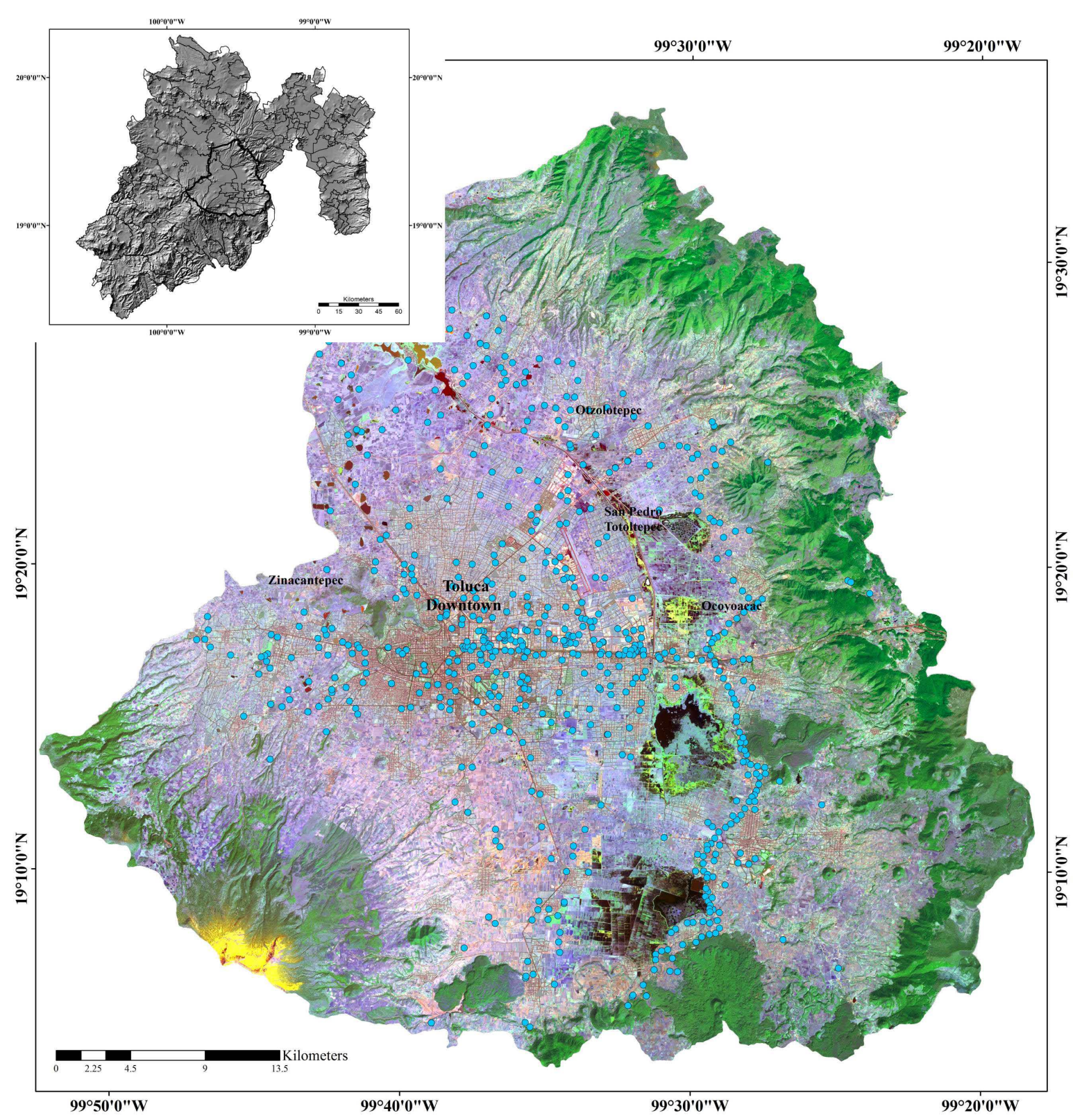

Figure 1. Study area location: Toluca Valley area within the border of the TVA. The blue points represent pumping wells.

Both of these systems correspond to Quaternary activity that is characterized by pyroclastic flows and unconsolidated material derived from volcanic explosive phases. These systems provide the principal means of aquifer recharge because of the rocks' high permeability. According to the geologic section shown in Figure 2, the geologic sequence in the study area can be characterized by three principal units. First, an explosive volcanic activity from Miocene to Quaternary with a rhyolitic to dacitic composition [33] [34]. Subsequently, the surficial geology is composed of sequences of lava flows and lahar deposits, over which there are settled lacustrine deposits that are composed of silt and clay sediments, principally located in the basin's center and eastern parts, and derived from relict lakes. Finally, alluvial deposits are distributed along the basin's flat area; these deposits originated from movement of upslope granular materials.

\section{Data}

We acquired 31 C-band Envisat-ASAR images taken along descending orbits, track 2190, for the period of 
NEVADO DE

TOLUCA VOLCANO

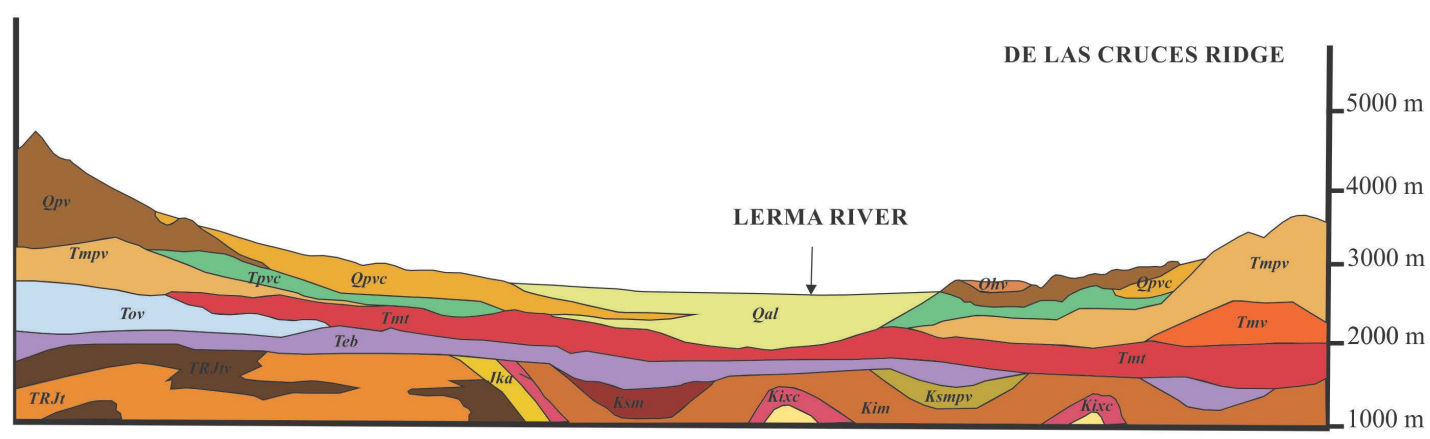

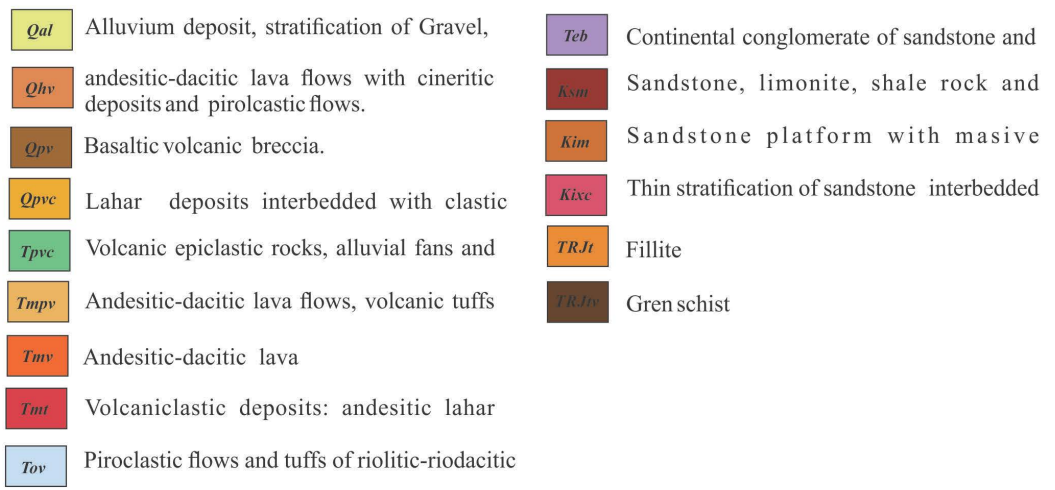

Figure 2. Geologic section of the TVA (modified from Honorio (1982)).

March 2003 to August 2010 (Table 1). Unfortunately, because of the failure of Envisat in April 2012, it was not possible to collect more recent radar data. A digital elevation model (DEM) proposed by INEGI (Instituto Nacional de Estadística Geografía e Informática) was used as an external DEM to remove the topographic phase from the differential interferograms. The images have a resolution of $30 \mathrm{~m}$ and were projected to the Universal Transverse Mercator (UTM) coordinate system with vertical coordinates specified by the World Geodetic System (WGS 84). PSI processing was performed using the ENVI SARSCAPE 5.0 software package, which has been specially calibrated for Envisat-ASAR data based on a linear model. To ensure optimal functioning of the software, 20 radar acquisitions must be considered at a minimum, and the software's accuracy may be increased by using radar acquisitions that are closely spaced in time.

\section{Methodology}

As mentioned above, the methodology to assess subsidence processes in the TVA is based on a linear model in which a constant velocity is considered as function of time. This assumption implies that variation in the displacement rate over time is not considered. Thus, the methodology can be explained as follows. The core of the PS analysis is the selection of point target candidates. As a result, criteria for implementing the method must be considered. The amplitude dispersion rule was used for the selection of point target candidates Ferreti et al. [26] [27]:

$$
D a=\frac{\sigma b}{\mu a}
$$

where $D a$ is the amplitude dispersion and $\sigma b$ and $\mu a$ represent the standard deviation and mean of the pixel amplitude over time, respectively. Thus, a pixel with low amplitude dispersion has a stable phase and is selected as a point target candidate. The selection and homogeneous distribution of point target candidates across the study area enables one to estimate the atmospheric contribution. A master image is selected to maximize the correlation (coherence) among all interferograms, which depends on the temporal and perpendicular baselines and differences in the Doppler centroid frequency along the baseline track [6] [9]. For the PSI analysis within 
Table 1. Baseline information for Envisat-ASAR.

\begin{tabular}{|c|c|c|c|}
\hline Date & Normal baseline & Temporal baseline & Layer type \\
\hline $26 / 03 / 2003$ & 0 & 0 & Master \\
\hline 09/07/2003 & 805.355 & 105.000 & Slave \\
\hline $13 / 08 / 2003$ & 910.537 & 140.000 & Slave \\
\hline $04 / 02 / 2004$ & 200.026 & 315.000 & Slave \\
\hline $10 / 03 / 2004$ & 494.118 & 350.000 & Slave \\
\hline $10 / 11 / 2004$ & 672.672 & 595.000 & Slave \\
\hline $15 / 12 / 2004$ & 382.021 & 630.000 & Slave \\
\hline $19 / 01 / 2005$ & 32.079 & 665.000 & Slave \\
\hline 08/06/2005 & 568.318 & 805.000 & Slave \\
\hline $17 / 08 / 2005$ & 113.325 & 875.000 & Slave \\
\hline $30 / 11 / 2005$ & 498.156 & 980.000 & Slave \\
\hline 08/02/2006 & 635.861 & 1050.000 & Slave \\
\hline $24 / 05 / 2006$ & 462.351 & 1155.000 & Slave \\
\hline 20/12/2006 & 15.830 & 1365.000 & Slave \\
\hline 28/02/2007 & 162.101 & 1435.000 & Slave \\
\hline $13 / 02 / 2008$ & 249.502 & 1785.000 & Slave \\
\hline $23 / 04 / 2008$ & 196.653 & 1855.000 & Slave \\
\hline 28/05/2008 & 100.487 & 1890.000 & Slave \\
\hline $15 / 10 / 2008$ & 54.675 & 2030.000 & Slave \\
\hline $24 / 12 / 2008$ & 146.143 & 2100.000 & Slave \\
\hline 04/11/2009 & 15.786 & 2415.000 & Slave \\
\hline 09/12/2009 & 390.494 & 2450.000 & Slave \\
\hline $13 / 01 / 2010$ & 1.350 & 2485.000 & Slave \\
\hline $17 / 02 / 2010$ & 62.130 & 2520.000 & Slave \\
\hline $24 / 03 / 2010$ & 123.901 & 2555.000 & Slave \\
\hline $28 / 04 / 2010$ & 19.817 & 2590.000 & Slave \\
\hline 02/06/2010 & 74.799 & 2625.000 & Slave \\
\hline 07/07/2010 & 49.727 & 2660.000 & Slave \\
\hline $11 / 08 / 2010$ & 141.117 & 2695.000 & Slave \\
\hline $15 / 09 / 2010$ & 122.686 & 2730.000 & Slave \\
\hline 20/10/2010 & 155.645 & 2765.000 & Slave \\
\hline
\end{tabular}

this area, the image acquired during February 2003 was selected as master, with a coherence limit of 0.75 . In addition, a maximum spatial baseline of $500 \mathrm{~m}$ and a maximum temporal baseline of 2590 days were selected. 


\section{Results}

After transforming the range to terrain correction, the PSI results were overlaid on a mosaic of Envisat-ASAR images (Figure 3) that show the line-of-sight (LOS) mean deformation velocity (mm/year). Considering all independent grids as a unique study area, 52,055 pixels were identified as PSs, with a density of 58 points $/ \mathrm{km}^{2}$. In the remainder of the study area, PS pixels are non-existent because of lost of coherence between all radar pairs.

The results of the LOS map indicate maximum land subsidence at a rate between -55 and -83 mm/year (i.e., color shades from orange to red on the map), getting a very close result in comparison to previous studies; however, potential areas and spatial variations of subsidence were determined.

A spatial comparison of the PS locations and the characteristics of the study area was performed. Almost 35\% are PS pixels with a subsidence rate greater than $-55 \mathrm{~mm} /$ year associated with the range greatest values of subsidence. The area that contains these PS pixels is located in the quadrant that is north-northeast-east of the historic downtown, which includes the villages of San Nicolas Tolentino, San Pedro Totoltepec, San Pablo Autopan and the airport area; where the subsidence processes come into land use of urban corridors with a high density of groundwater pumping, agricultural areas and industrial equipment. The second area with high subsidence values corresponds to the western border of TC; this area exhibits a subsidence rate of -40 to $-60 \mathrm{~mm} / \mathrm{year}$ (color shades from yellow to orange on the map) and a low density of $9 \%$ of PS pixels. The land use in this area is primarily characterized by peri-urban settlements and agricultural areas with a low density of groundwater pumping.

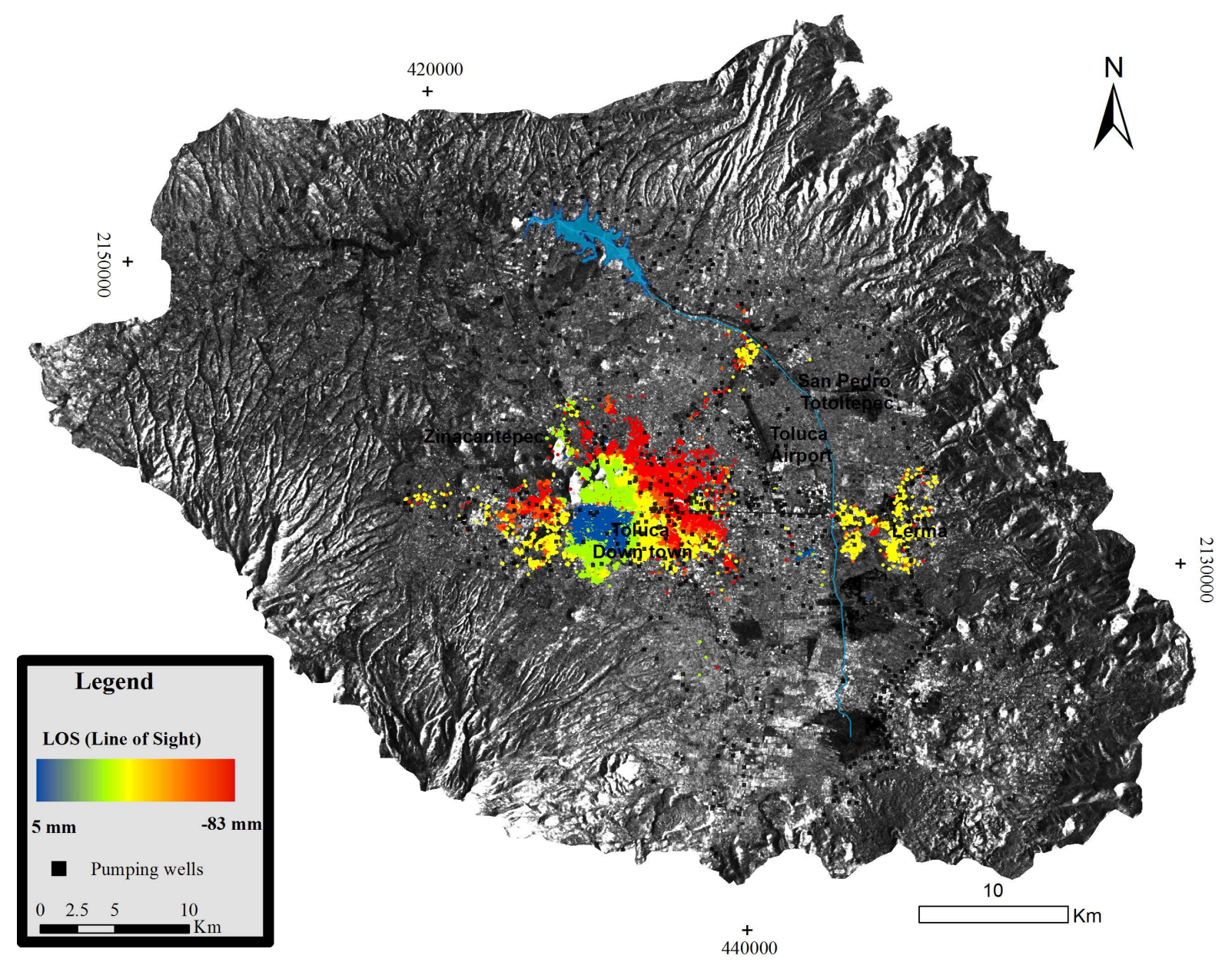

Figure 3. PSI results for the evaluation of subsidence in Toluca Valley for the period 2003-2010 using 31 Envisat-ASAR images. 


\section{Validation of PSI-Time Series Analysis and Discussion}

Worldwide, there are numerous examples that demonstrate the intrinsic relationship between ground subsidence (identified using DinSAR techniques) and groundwater overexploitation in urban environments [4] [8] [10] [28] [29] [35]-[37]. In Mexico, several case studies have reported an intrinsic relationship between the location of ground subsidence and soil compaction (of the upper layers of soils rich in clay) due to decreases in the groundwater level. This effect is especially evident in MC, where the maximum total subsidence was approximately $400 \mathrm{~mm}$ for the period from 2002 to 2010; this value is considered the maximum vertical deformation associated with ground subsidence process throughout Mexico [4].

To determine the accuracy of the results obtained from PSI, a comparison of PSI and piezometric monitoring was realized to analyze the vertical fluctuations of groundwater level at different depths through time and to compare the spatial distribution of groundwater fluctuations with that of vertical ground deformation (i.e., the LOS mean deformation). Near to 150 multi-piezometers are distributed across the basin and were installed at a rate between 5 and $350 \mathrm{~m}$ of depth. We chose those sensor multi-piezometers specifically located at 3 depths of 50, 100, and $150 \mathrm{~m}$. Finally, only 31 multi-piezometers were selected for the validation process. According to the lithological sequence of the multi-piezometers selected, its conformed in 2 units associated to the Late Pliocene-Quaternary [38]. The first unit is characterized by overlaid volcanoclastic and lacustrine deposits, which are predominantly composed of clay; the second unit is a minor layer of unconsolidated alluvial deposits (which is composed of gravel, silt, and clay).

Three final maps were generated using an algorithm based on a geo-statistical interpolation method:

$$
Y\left(X_{o}\right)=\sum_{l=1}^{N} \lambda_{i} Y\left(X_{i}\right)
$$

where $Y\left(X_{i}\right)$ is the predicted measurement at location $i, \lambda_{i}$ is an unknown weight of the measured value at location $i$, and $Y\left(X_{o}\right)$ is the prediction at location $i$. This formula considers the data-weighted sum, where the spatial correlation is considered for a given set of points (within a specified radius), thus obtaining a measure of the accuracy of the predictions about unmeasured locations.

Thus, the maps in Figure 4 show the spatial evolution of the groundwater level through the period 1970-2010, considering only the following 3 levels of depth: 50, 100, and $150 \mathrm{~m}$. Interpolation of the piezometric time series demonstrates that a minimum vertical fluctuation of the groundwater level occurs at shallow depths (Figure 4(A)). The maximum fluctuations occur at depths greater than $100 \mathrm{~m}$, with an oscillation greater than $47 \mathrm{~m}$. Specifically, there is a spatial correlation between isolines linked to maximum piezometric fluctuations and subsidence rates of greater than $-40 \mathrm{~mm} /$ year, which indicates a possible expanding trend of subsidence process at north, northeast and east of the TVA (Figure 4(B) and Figure 4(C)).

To show the patterns of aquifer depletion through time with respect to the PSI results, we selected 4 profiles along different windows with the same dimensions extracted from subsidence LOS map. The criterion for locating of the windows was based on a spatial limit between low, medium, and high values of subsidence with respect to the nearest piezometer (see Figure 4). The graphics in Figure 5 correspond to the multi-piezometers PL-130, PL-201, PL-202, and PL-205 and consider the same period of time as the PSI analysis (2003-2010). PL-130 (Figure 5(A)) is located at the eastern edge of the TVA, the graphic represents the evolution for three different groundwater levels: $151 \mathrm{~m}, 121 \mathrm{~m}$, and $11 \mathrm{~m}$; which exhibit constant behavior for the time period considered. However, according to the PS values, the total land subsidence reaches $-37 \mathrm{~mm} /$ year, with a major density of PSs in the period 2009-2010. PL-201 is the piezometer that is nearest to the historic center of Toluca City, and its spatial position represents the limit of the medium subsidence values, with rates of -40 to $-65 \mathrm{~mm} / \mathrm{year}$. The graphic shows the evolution of the vertical gradient for the aquifer's shallow levels at depths of $12 \mathrm{~m}, 23 \mathrm{~m}$, and $50 \mathrm{~m}$ (Figure 5(B)); the maximum fluctuation is approximately $-5 \mathrm{~m}$ for the sounding lines at $23 \mathrm{~m}$ and 50 $\mathrm{m}$, which is not a significant change in the vertical gradient of the aquifer. Nevertheless, the sounding line at 12 $\mathrm{m}$ indicates a recovery in the level water of approximately $4 \mathrm{~m}$ for the period 2005-2009. PL-205, which is located at the northeast edge, measured the greatest values of subsidence over the entire LOS map (rates between $-55 \mathrm{~mm} /$ year and $-83 \mathrm{~mm} /$ year) and exhibits a similar behavior for the shallow sounding lines (17 $\mathrm{m}$ of depth). Otherwise occurs with the sounding lines greater than $100 \mathrm{~m}$, where there is a negative tendency for groundwater levels with an abatement gradient of $-40.99 \mathrm{~m}$ to $-45.99 \mathrm{~m}$ (Figure $5(\mathrm{C})$ ). Finally, PL-202 exhibits a similar behavior for sounding lines at depths of greater than $100 \mathrm{~m}$ : the graphic (Figure 5(D)) shows an abatement of 


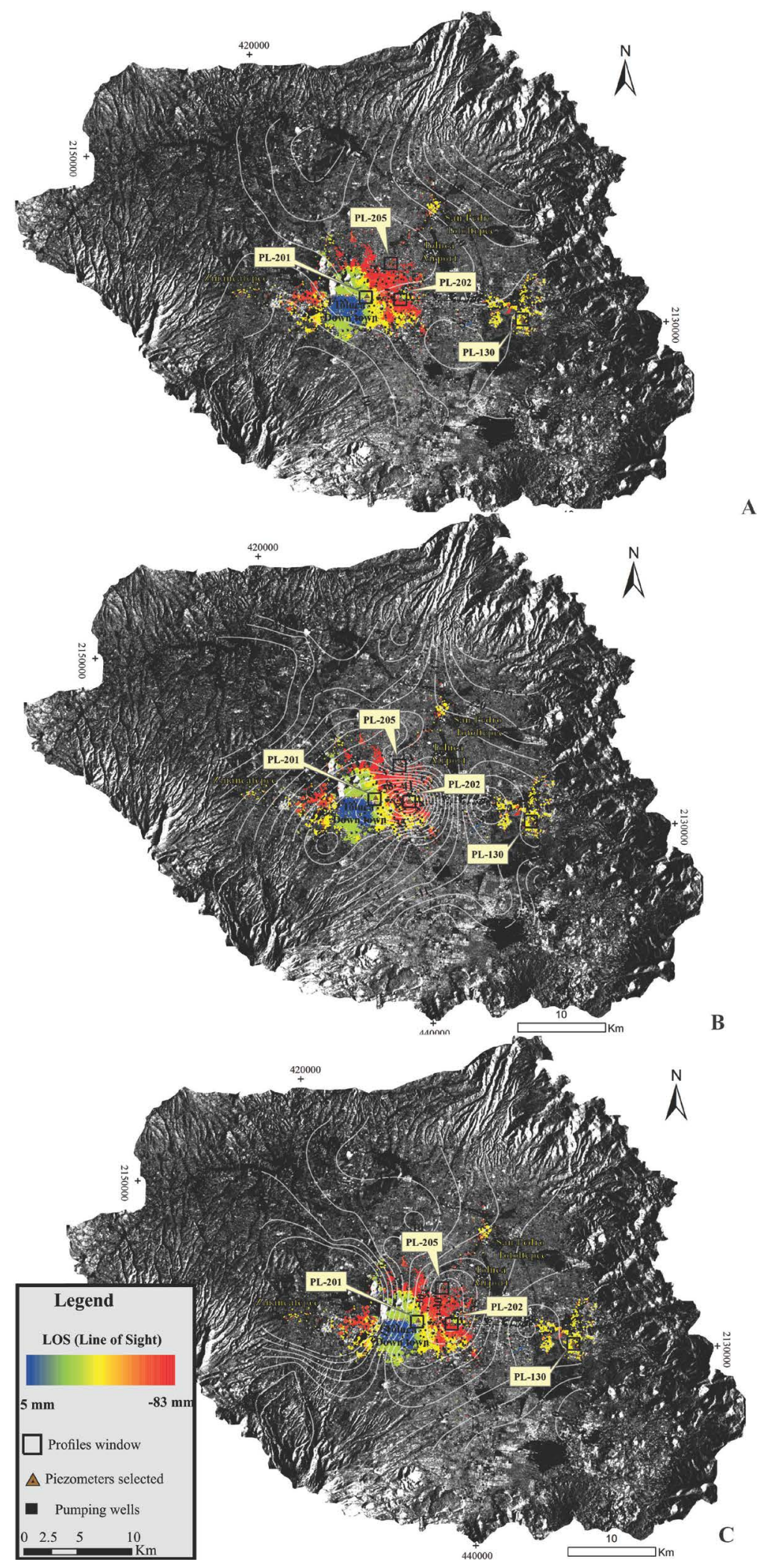

Figure 4. Distribution of PSs with respect to isolines of maximum piezometric fluctuations for the period 1970-2010 considering only three levels of depth: 50 $\mathrm{m}(\mathrm{A}), 100 \mathrm{~m}(\mathrm{~B})$, and $150 \mathrm{~m}(\mathrm{C})$. 

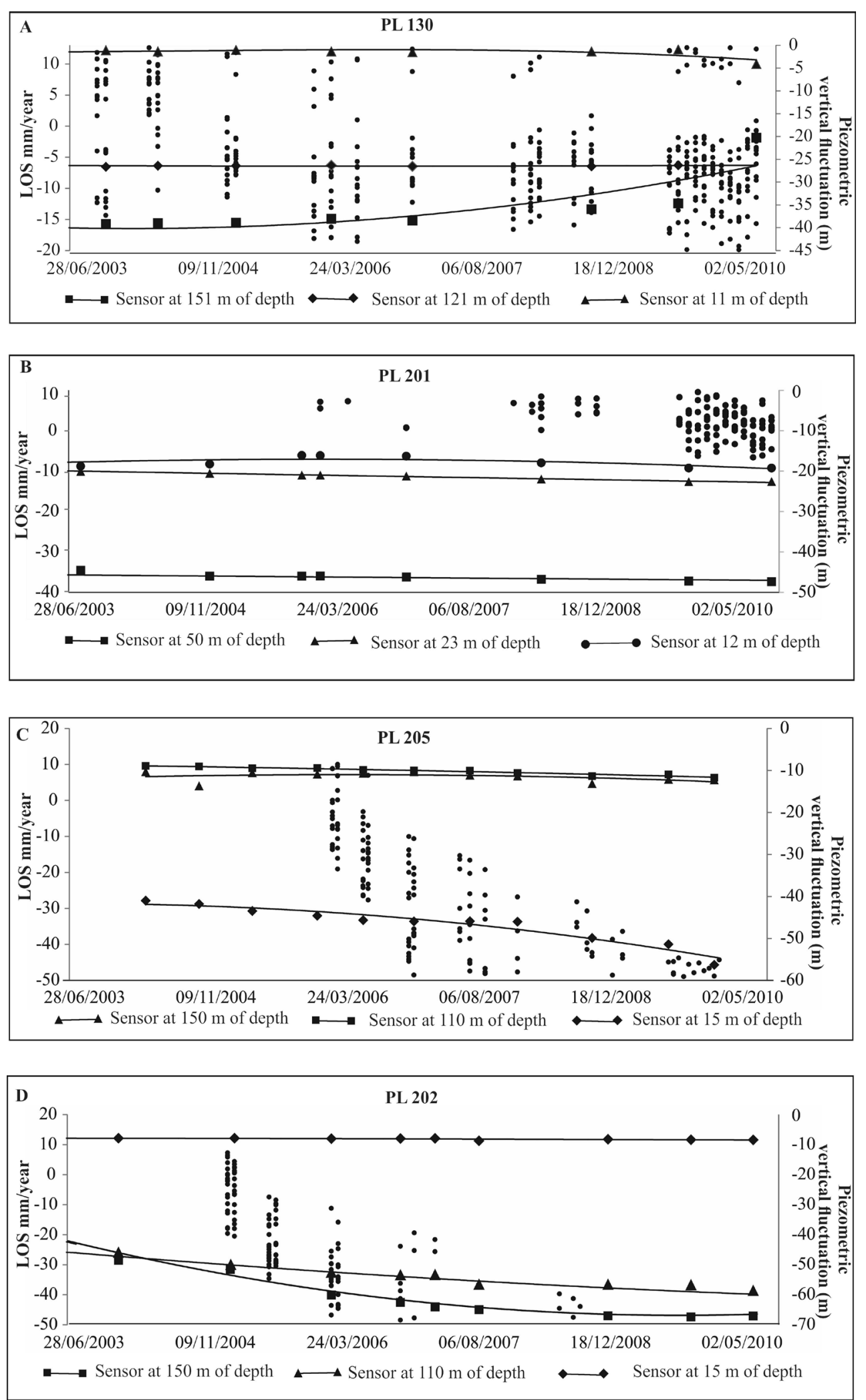

Figure 5. Graphics of the profiles along the selected windows (see Figure 4). The graphics show the historical relationship between piezometric data and the LOS map for the period 2003-2010. The multi-piezometers selected were PL-130 (A), PL-201 (B), PL-205 (C), and PL-202 (D). 
the groundwater table during all periods of time (2003-2010). Specifically, the sounding line at a depth of $150 \mathrm{~m}$ is where the maximum abatement gradient of the groundwater level is $-28.27 \mathrm{~m}$.

Thus, according to the validation that compared the PSI and piezometric data, there is no evidence of a direct relationship between ground subsidence and the static level of groundwater in the TVA at depths less than $50 \mathrm{~m}$. This finding could be attributed to local confinement of the aquifer, which is conformed by sequences of lacustrine and alluvial deposits that are interconnected by the lateral flow of water. Alternatively, there is a direct correlation between a high rate of subsidence derived from PSI multi-temporal analysis and historical piezometric data along chosen profiles, specifically for sounding lines that are up to $100 \mathrm{~m}$ deep. This finding also considers that the maximum isoline's density corresponds with the maximum rate of depletion of the static groundwater level, which could be an indicator of a spatial trend in land subsidence. This trend would imply that the sector to the north, northeast, and east of the city exhibits the possibility of an expanding trend of subsidence process.

\section{Conclusion}

In this paper, we presented an approach for detecting land subsidence in the TVA based on PSI method. A high spatial correlation was identified for PSs with a rate between -55 and $-83 \mathrm{~mm} /$ year and maximum groundwater level depletion rates of up to $-47 \mathrm{~m}$, considering historical piezometric data at depths of up to $100 \mathrm{~m}$ for 19702010. Because of overexploitation of the aquifer, the spatial distribution of PS pixels and the behavior of abatement isolines possibly indicate increasing land subsidence in the northeast quadrant of the TVA, where the highest density of pumping wells for industrial and farm use is located. The PSI method in combination with hidrological data is a potential technique for the spatial and temporal monitoring of subsidence, which should be considered for decision-making about land planning programs in urban and suburban areas.

\section{Acknowledgements}

We gratefully acknowledge the ESA (European Space Agency) for providing Envisat-ASAR data by through Proposal-Project PI-11456. This study is part of the project F-PROMEP-38/Rev-03 SEP-23-005.

\section{References}

[1] Ferreti, A., Prati, C., Rocca, F. and Wasowski, J. (2006) Satellite Interferometry for Monitoring Ground Deformations in the Urban Environment. Proceedings 10th IAEG Congress, Nottingham, 100-110.

[2] Guéguen, Y., Deffontaines, B., Fruneau, B., Heib, M. and Raucoules, D. (2009) Monitoring Residual Mining Subsidence of Nord/Pas-de-Calais Coal Basin from Differential and Persistent Scatterer Interferometry (Northern France). Journal of Applied Geophysics, 69, 24-34. http://dx.doi.org/10.1016/j.jappgeo.2009.02.008

[3] Parcharidis, M., Foumelis, M., Kourkouli, P. and Wegmuller, U. (2009) Persistent Scatterer InSAR to Detect Ground Deformation over Rio-Antirio Area (Western Greece) for Period 1992-2000. Journal of Applied Geophysics, 68, 348355. http://dx.doi.org/10.1016/j.jappgeo.2009.02.005

[4] López, P., Doin, M., Tupin, F., Briole, P. and Nicolas, J. (2009) Time Series Analysis of Mexico City Subsidence Constrained by Radar Interferometry. Journal of Applied Geophysics, 69, 1-15. http://dx.doi.org/10.1016/j.jappgeo.2009.02.006

[5] Heleno, S., Oliveira, L., Henriques, M., Falcão, A., Lima, J., Cooksley, G., Ferretti, A., Fonseca, A., Lobo, J. and Fonseca, J. (2011) Persistent Scatterers Interferometry Detects and Measures Ground Subsidence in Lisbon. Remote Sensing of Environment, 115, 2152-2167. http://dx.doi.org/10.1016/j.rse.2011.04.021

[6] Sousa, J., Ruiz, A., Hanssen, R., Bastos, L., Gil, A., Galindo, J. and Sanz, C. (2010) PS-InSAR Processing Methodologies in the Detection of Field Surface Deformation-Study of the Granada Basin (Central Betic Cordilleras, Southern Spain). Journal of Geodynamics, 49, 181-189. http://dx.doi.org/10.1016/j.jog.2009.12.002

[7] Hung, W., Hwang, Ch., Chen, Y., Chang, Ch., Yen, J., Hooper, A. and Yang, Ch. (2011) Surface Deformation from Persistent Scatterers SAR Interferometry and Fusion with Leveling Data: A Case Study over the Choushui River Alluvial Fan, Taiwan. Remote Sensing of Environment, 115, 957-967. http://dx.doi.org/10.1016/j.rse.2010.11.007

[8] Osmanoglu, T., Wdowinski, S., Cabral, E. and Jiang, Y. (2011) Mexico City Subsidence Observed with Persistent Scatterer InSAR. International Journal of Applied Earth Observation and Geoinformation, 13, 1-12. http://dx.doi.org/10.1016/j.jag.2010.05.009

[9] Tung, H. and Hu, J. (2012) Assessments of Serious Anthropogenic Land Subsidence in Yunlin County of Central Tai- 
wan from 1996 to 1999 by Persistent Scatterers InSAR. Tectonophysics, 578, 126-135.

http://dx.doi.org/10.1016/j.tecto.2012.08.009

[10] Cigna, F., Osmanoğlu, B., Cabral, E. and Dixon, T. (2011) Monitoring Land Subsidence and Its Induced Geological Hazard with Synthetic Aperture Radar Interferometry: A Case Study in Morelia, Mexico. Remote Sensing of Environment, 117, 146-161. http://dx.doi.org/10.1016/j.rse.2011.09.005

[11] Chaussard, E., Wdowinski, S., Cabral, E. and Amelung, F. (2014) Land Subsidence in Central Mexico Detected by ALOS InSAR Time-Series. Remote Sensing of Environment, 104, 94-106. http://dx.doi.org/10.1016/j.rse.2013.08.038

[12] Hooper, A. (2008) A Multi-Temporal InSAR Method Incorporating Both Persistent Scatterer and Small Baseline Approaches. Geophysics Research Letters, 35, Article ID: L16302. http://dx.doi.org/10.1029/2008GL034654

[13] Pinel, V., Hooper, A., De la Cruz, G., Reyes, G. and Doin, M. (2011) The Challenging Retrieval of Displacement Field from InSAR Data for Andesitic Stratovolvanoes: Case Study of Popocatepetl and Colima Volcano, Mexico. Journal of Volcanology and Geothermal Research, 200, 49-61. http://dx.doi.org/10.1016/j.jvolgeores.2010.12.002

[14] Catalano, S., Bonforte, A., Guglielmino, F., Romagnoli, G., Tarsia, C. and Tortorici, G. (2013) The Influence of Erosional Processes on the Visibility of Permanent Scatterers Features from SAR Remote Sensing on Mount Etna (E Sicily). Geomorphology, 198, 128-137. http://dx.doi.org/10.1016/j.geomorph.2013.05.020

[15] Magnússon, E., Björnsson, H., Rott, H., Roberts, M., Pálsson, F., Gudmundsson, S., Bennett, R., Geirsson, H. and Sturkell, E. (2011) Localized Uplift of Vatnajökull, Iceland: Subglacial Water Accumulation Deduced from InSAR and GPS Observations. Journal of Glaciology, 57, 475-484. http://dx.doi.org/10.3189/002214311796905703

[16] Rignot, E., Mouginot, J. and Scheuchl, B. (2011) Antarctic Grounding Line Mapping from Differential Satellite Radar Interferometry. Geophysical Research Letters, 38, Article ID: L10504. http://dx.doi.org/10.1029/2011GL047109

[17] Castañeda, C., Gutiérrez, F., Manunta, M. and Galve, J. (2009) DInSAR Measurements of Ground Deformation by Sinkholes, Mining Subsidence, and Landslides, Ebro River, Spain. Earth Surfaces Processes and Landforms, 34, 15621574. http://dx.doi.org/10.1002/esp.1848

[18] Holbling, D., Fureder, P., Antolini, F., Cigna, F., Casagli, N. and Lang, S. (2013) A Semi-Automated Object-Based Approach for Landslide Detection Validated by Persistent Scatterer Interferometry Measures and Landslide Inventories. Remote Sensing, 4, 1310-1336. http://dx.doi.org/10.3390/rs4051310

[19] Dong, S., Yin, H., Yao, S. and Zhang, F. (2013) Detecting Surface Subsidence in Coal Mining Area Based on DInSAR Technique. Journal of Earth Science, 24, 449-456. http://dx.doi.org/10.1007/s12583-013-0342-1

[20] Sarychikhina, O., Glowacka, E. and Mellors, R. (2007) Preliminary Results of a Surface Deformation Study, Using Differential InSAR Technique at the Cerro Prieto Geothermal Field, B.C., Mexico. Renewable Baseload Energy: Geothermal Heat Pumps to Engineered Reservoirs, Reno, 30 September 2007.

[21] Hunstad, I., Pepe, A., Atzori, S., Tolomei, C., Salvi, S. and Lanari, R. (2009) Surface Deformation in the Abruzzi Region, Central Italy, from Multitemporal DInSAR Analysis. Geophysical Journal International, 178, 1193-1197. http://dx.doi.org/10.1111/j.1365-246X.2009.04284.X

[22] Currenti, G., Solaro, G., Napoli, R., Pepe, A., Bonaccorso, A., Del Negro, C. and Sansosti, E. (2012) Modeling of ALOS and COSMO-SkyMed Satellite Data at Mt Etna: Implications on Relation between Seismic Activation of the Pernicana Fault System and Volcanic Unrest. Remote Sensing of Environment, 125, 64-72. http://dx.doi.org/10.1016/j.rse.2012.07.008

[23] Zebker, H.A. and Villasenor, J. (1992) Decorrelation in Interferometric Radar Echoes. IEEE Transactions on Geoscience and Remote Sensing, 30, 950-959. http://dx.doi.org/10.1109/36.175330

[24] Zebker, H.A., Rosen, P.A. and Hensley, S. (1997) Atmospheric Effects in Interferometric Synthetic Aperture Radar Surface Deformation and Topographic Maps. Journal of Geophysical Research, 102, 7547-7563. http://dx.doi.org/10.1029/96JB03804

[25] Hanssen, R.F. (2001) Radar Interferometry: Data Interpretation and Error Analysis. Remote Sensing and Digital Image Processing, 3, 308.

[26] Ferretti, A., Prati, C. and Rocca, F. (2000) Nonlinear Subsidence Rate Estimation Using the Permanent Scatterers in Differential SAR Interferometry. IEEE Transactions on Geoscience and Remote Sensing, 38, 2202-2012. http://dx.doi.org/10.1109/36.868878

[27] Ferretti, A., Prati, C. and Rocca, F. (2001) Permanent Scatterers in SAR Interferometry. IEEE Transactions on Geoscience and Remote Sensing, 39, 8-20. http://dx.doi.org/10.1109/36.898661

[28] Calderhead, A., Martel, R., Alasset, P., Rivera, A. and Garfias, J. (2010) Land Subsidence Induced by Groundwater Pumping, Monitored by D-InSAR and Field Data in the Toluca Valley, Mexico. Canadian Journal of Remote Sensing, 36, 9-23. http://dx.doi.org/10.5589/m10-024

[29] Calderhead, A., Therrien, R., Rivera, A., Martel, R. and Garfias, J. (2011) Simulating Pumping-Induced Regional Land Subsidence with the Use of InSAR and Field Data in the Toluca Valley, Mexico. Advances in Water Resources, 34, 
83-97. http://dx.doi.org/10.1016/j.advwatres.2010.09.017

[30] Yan, Y., Doin, M., López, P., Tupin, F., Fruneau, B., Pinel, V. and Trouvé, E. (2012) Mexico City Subsidence Measured by InSAR Time Series: Joint Analysis Using PS and SBAS Approaches. IEEE Journal of Selected Topics in Applied Earth Observations and Remote Sensing, 4, 1312-1326.

[31] Garfias, J., Bibiano, L. and Llanos, C. (2008) Uso racional y sostenible de los recursos hídricos del acuífero del valle de Toluca. Ciencia Ergo Sum, 15, 61-72.

[32] Comisión Nacional del Agua (2009) Estadísticas del Agua de la Región Hidrológico-Administrativa XIII, Aguas del Valle de México. Comisión Nacional del Agua, México.

[33] Sultan, R. (2001) Impacts on Wetland Hydrology from Extensive Groundwater Extraction: Lerma River Basin, Mexico. A Thesis of Master of Science in Earth Sciences, University of Waterloo, Canada.

[34] Diez, A. (2010) Alternativas de administración racional de recursos hídricos en el acuífero sometido a sobreexplotación: Valle de Toluca. A PhD Thesis, Universidad Autónoma del Estado de México, México.

[35] Farina, P., Ávila, J. and Garduño, V. (2007) Structurally-Controlled Urban Subsidence along the Mexican Volcanic Belt (MVB) Monitored by InSAR. Proceedings of Envisat Symposium, Montreux, 23-27 April 2007.

[36] Pacheco, J. and Arzate, J. (2007) Análisis multicapa de la subsidencia en el valle de Querétaro, México. Revista Mexicana de Ciencias Geológicas, 24, 389-402.

[37] Sarychikhina, O., Glowacka, E., Vidal, F., Mellors, R. and Ramírez, J. (2011) Aplicación de DInSAR a los estudios de subsidencia en el Valle de Mexicali. Boletín de la Sociedad Geológica Mexicana, 63, 1-13.

[38] Honorio, R. and Hernández, H. (1982) Origen, estratigrafía y petrología de la Cuenca de México y sierras circunvecinas. A Thesis of Master, IPN-ESIA-México. 